\title{
Pharmacognostical and Proximal Analysis of Two different Extracts (Methanol and Aqueous) of Indian Endangered Coscinium fenestratum Stem
}

\author{
Kuntal Das* \\ Krupanidhi College of Pharmacy, Chikkabellandur, Varthur Hobli, Karnataka, Bangalore, INDIA.
}

\begin{abstract}
Background: Coscinium fenestratum (CF) (Family: Menispermaceae), an endangered and highly commercial medicinal plant of traditional system of medicine. Stem is commercially important which have multiple medicinal used and therapeutic efficacy. The objective of the study is to evaluate the effect of extraction, content of elements and their correlation on proximate analysis and detection of compound in various extracts of Indian endangered Coscinium fenestratum stem. Materials and Methods: Proximate analysis in terms of moisture content, ash values, extractive values and crude fibres are determined as per AOAC method. Arrangement of stem fibres is detected with SEM. Presence of secondary metabolites in both the extracts performed through chemical tests. Elemental analysis was carried out by digestion method using Atomic Absorption Spectrophotometer. Results: Powder microscopy as well as SEM analysis revealed the presence of fibres, cork cells, cortex, tracheids, pitted wood elements and Xylems, Prismatic calcium oxalate crystals, stone cells, Medullary rays, phloem fibres etc. Elemental analysis revealed high content of elements in microwave extracted aqueous extract than soxhlet extracted sample. Chemical tests resulted high content of alkaloid, phenolics and flavonoids in microwave extracted methanolic extract. Conclusion: This was the first report on this plant about basic mechanism for presence of phytoconstituents in higher amount influenced by various elements as well as anatomical identification of stem cells and tissues through SEM analysis.
\end{abstract}

Key words: Coscinium fenestratum, Proximate, Elemental analysis, Microscopic character, SEM.

\section{INTRODUCTION}

Coscinium fenestratum (CF) (Gaertn.) (Family: Menispermaceae) plant is critically endangered medicinal plant of India especially in Karnataka, Kerala and Tamil Nadu. This is due to more than $80 \%$ decline in the wild populations more than three decades and slow germination rate. ${ }^{1}$ The plant is woody climber and commonly known as yellow vine or tree turmeric or false calumba. ${ }^{2}$ It is commonly distributed throughout Western Ghats region of India and Sri Lanka. The stem is having economical demand as well therapeutic efficacy with a vast number of ayurvedic preparations. ${ }^{3}$ It is used as detoxifying agent, reduce blood sugar level and cholesterol and maintain blood pressure. ${ }^{4}$ Pharmacologically the stem is effective against Neisseria gonorrhoeae and acts as antigonococcal agent ${ }^{5}$ and hepatoprotective activity. ${ }^{6}$ The plant is also used in opthalmopathy, inflammation, ulcers, skin disease, abdominal disorders, fever, snake bite as well as wound healings. ${ }^{7-9}$ These activities are mainly due to presence of active constituents. The main active constituents yellow crystalline berberine, protoberberine and jatrorrhizine that are present in this plant show enormous therapeutic applications. Thereafter Ecdysterone was also isolated from the methanolic stem extract
Submission Date: 01-08-2019; Revision Date: 27-09-2019; Accepted Date: 08-11-2019

DOI: 10.5530/ijper.53.4s.168 Correspondence: Dr. Kuntal Das, Krupanidhi College of Pharmacy, Chikkabellandur, Carmelaram Post, Varthur Hobli-560035, Bangalore, Karnataka, INDIA.

Phone: +919632542846

E-mail: drkkdsd@gmail.com

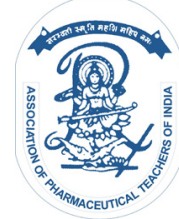

www.ijper.org 
of $\mathrm{CF}$ and quantified. ${ }^{10}$ The leaves are simple, alternate, exstipulate, broadly ovate and rounded and fruits are rounded. Many literatures reviewed about morphology and microscopy of CF leaves ${ }^{11,12}$ but no reports or very scanty reports on microscopic nature of stem of $\mathrm{CF}^{12,13}$ thereafter no such scientific evidences on scanning electron microscopy (SEM) study of stem powders and proximate analysis such as moisture content, ash content and extractive values and elemental analysis. Interestingly there are no reports on correlation among the elemental effects, extraction methods as well as yield of extracts on alkaloid content for the said stem. Looking at the earlier research evidences the present study is first time revealed with the aim of evaluation of detail Pharmacognostical screening, microscopic evaluation followed by SEM study, phytochemical detection of various extracts through TLC and estimation of total alkaloid, phenolics and flavonoids contents in this CF stem.

\section{MATERIALS AND METHODS}

\section{Collection of plant materials}

CF stem was collected from Indian Institute of Horticultural Research, Hessaraghatta, Bengaluru in 2017 in April-May month from Department of Plant biotechnology and the same was authenticated by Dr. Rajasekharan P.E, Principal Scientist in the same department. The stem was preserved in our Pharmacognosy laboratory as herbarium (Herbarium numbers: KDCFSTEM/KCP-97/2017).

\section{Proximate analysis of CF stem}

The powdered stem of CF was subjected to evaluate various ash contents such as total ash, acid insoluble ash, alcohol soluble ash, water and alcohol soluble extractive values, moisture content, crude fiber content, elemental analysis etc.

\section{Total ash content}

Total ash content was determined as per method of AOAC. ${ }^{14} 1 \mathrm{~g}$ of dried powdered stem sample was kept in a silica crucible in a muffle furnace with temperature of at $450^{\circ} \mathrm{C}$ for $2-3 \mathrm{hr}$. After ash, it was then cooled in a desiccator and weighed. It was once again heated in the muffle furnace for half an hr, cooled and weighed. The procedure was repeated until to get the constant weight. Total ash content was determined with the following formula:

$$
\text { Percentage of ash }=\frac{\text { Weight of ashed sample }}{\text { Weight of sample taken }} \times 100
$$

\section{Alcohol soluble ash}

The soluble ash was determined by using ethanol as solvent. The ash obtained was digested with $25 \mathrm{ml}$ of ethanol for 20- $30 \mathrm{~min}$ in a boiling water bath. The content in the silica crucible was filtered by using ash less filter paper (Whatman filter paper No: 42). The filter paper with residue was removed carefully without any loss, folded and put in the same crucible. Then dried in hot air oven and ignited in muffle furnace at $600^{\circ} \mathrm{C}$ for $1 \mathrm{~h}$. Then it was cooled in a desiccator and weighed. The soluble ash value was determined as per the formula given below ${ }^{15}$

Percentage of ethanol soluble ash $=\frac{\text { Weight of soluble ash }}{\text { Total weight of ash }} \times 100$

\section{Acid insoluble ash}

The ash obtained under total ash value was boiled with $25 \mathrm{ml}$ of $2 \mathrm{~N} \mathrm{HCl}$ for 5 to $10 \mathrm{~min}$. Then the solution was filtered on an ash less filter paper and the insoluble matter was collected. This insoluble matter was further washed with hot water, ignited and weighed. The percentage of acid insoluble ash was calculated with reference to the air dried drug.

\section{Moisture content}

The crucible was placed inside the drying oven at $105^{\circ} \mathrm{C}$ for $2 \mathrm{hr}$. Then the crucible was placed in the desiccators and cooled. The beaker was weighed and $2 \mathrm{~g}$ of the powder was placed in the beaker. The sample was dried in oven at $105^{\circ} \mathrm{C}$ for $3 \mathrm{hr}$. Then the dried sample was weighed after cooled and percent of moisture content in sample was determined as per following formula ${ }^{15}$

Percentage of moisture content $=\underline{\text { Weight of sample }- \text { Weight of dried sample }} \times 100$

Weight of sample

\section{Extractive values}

Weighed $5 \mathrm{~g}$ of coarsely powdered stem of $\mathrm{CF}$ and was subjected to macerate for $24 \mathrm{hr}$ in a closed iodine flask using $100 \mathrm{ml}$ of two different solvents viz. alcohol and distilled water. The flask was frequently shaken during the first $6 \mathrm{hr}$ and then allowed to stand for overnight $(24 \mathrm{hr})$. After $24 \mathrm{hr}$, the content in the flask was filtered using Whatman No: 42 filter paper and poured $20 \mathrm{ml}$ in a big flatted perti plate and the filtrate was evaporated to dryness in hot air oven at $105^{\circ} \mathrm{C}$ and weighed after dried. The percentage of soluble extractive was calculated as follows:

Percentage of extracting value $=\frac{\text { Weight of flask with extract }- \text { Weight of empty flask }}{\text { Weight of sample }} \times 100$

\section{Crude fiber}

Weight of sample

In a $250 \mathrm{ml}$ conical flask $2 \mathrm{~g}$ of powdered samples separately mixed with $1.25 \%$ Sulfuric acid solution. The 
samples were heated about 30 min and was vacuum filtered, then washed until traces of acid were removed. The Whatman paper was placed in the Buchner flask. After that the acid extracted was transferred into 250 $\mathrm{ml}$ conical flask and $1.25 \%$ sodium hydroxide solution was added. The samples were heated again for $30 \mathrm{~min}$ and were filtered using vacuum filter and washed with water until base was undetected. The whole material was transferred separately into silica crucibles and dried for $12 \mathrm{hr}$ at $120^{\circ} \mathrm{C}$. After that the crucibles were placed into muffle furnace at $550^{\circ} \mathrm{C}$ for $6-8 \mathrm{hr}$ until ash obtained. The weight of fiber was determined by difference ${ }^{16}$ and calculated as per following formula

$\%$ crude fiber $=$

(Wt. of crucible + sample after washing and drying $)$ - (Wt. of crucible + ash $) \times 100$ Wt. of sample taken

Scanning Electron Microscope (SEM) study was performed to understand the arrangement of fibers and their strength was determined for mechanism of climber plant.

\section{Powder microscopy}

Shade dried stem was finely powdered and studied under microscope. Small quantity of stem powder was placed separately on slides and each slide was mounted 2-3 drops of chloral hydrate and each slide was covered with cover slip then examined under microscope. Different cell components were noted and photography was recorded. The same was confirmed with SEM study.

\section{Elemental analysis}

Elements like Zinc ( $\mathrm{Zn})$, Iron (Fe), copper (Cu), Lead $(\mathrm{Pb})$, Cadmium (Cd), Chromium (Cr), Nickel (Ni), Arsenic (As), Sodium ( $\mathrm{Na}$ ), Potassium (K), Calcium (Ca) were determined for powdered as well as extracted CF stem samples separately by Atomic absorption spectrometer (Analytik Jena AG, Jena, Germany) with an air/acetylene flame and respective hollow-cathode lamps was used for absorbance measurements. Triacid mixture was used (mixed with concentrated nitric acid $100 \mathrm{ml}$, concentrated sulphuric acid $10 \mathrm{ml}$ and $40 \mathrm{ml}$ of $60 \%$ perchloric acid).

$2 \mathrm{~g}$ of powdered stem sample mixed with $6 \mathrm{ml}$ of ternary acid mixture and digestion was carried out at $180^{\circ} \mathrm{C}$ to $200^{\circ} \mathrm{C}$ until dense white fumes were evolved and formed residue and further was diluted with glass distilled water and made up to definite volume in a volumetric flask. Then the solution was ready for determination of $\mathrm{Fe}, \mathrm{Cu}$ and $\mathrm{Zn}$ and toxic heavy metals like $\mathrm{Cd}, \mathrm{Cr}, \mathrm{Pb}, \mathrm{As}$ and $\mathrm{Ni}$. Wavelengths and slits used for the determination of elements were $248.3 \mathrm{~nm}, 0.2 \mathrm{~mm}$, (Fe): $324.8 \mathrm{~nm}, 1.2 \mathrm{~mm}(\mathrm{Cu}): 213.9 \mathrm{~nm}, 0.5 \mathrm{~mm}(\mathrm{Zn})$ :
$326.1 \mathrm{~nm}, 0.5 \mathrm{~mm}(\mathrm{Cd}): 357.9 \mathrm{~nm}, 0.2 \mathrm{~mm}(\mathrm{Cr}): 283.3$ $\mathrm{nm}, 1.0 \mathrm{~mm}(\mathrm{~Pb}): 193.7 \mathrm{~nm}, 0.2 \mathrm{~mm}(\mathrm{As}): 232.0 \mathrm{~nm}$, $0.2 \mathrm{~mm}(\mathrm{Ni})$ respectively. Further $\mathrm{Na}, \mathrm{K}$ and $\mathrm{Ca}$ were determined with following wavelength and slit diameter: $589 \mathrm{~nm}, 0.3 \mathrm{~mm}(\mathrm{Na}) ; 383.3 \mathrm{~nm}, 3 \mathrm{~mm}(\mathrm{~K}) ; 239.86 \mathrm{~nm}$, $3.0 \mathrm{~mm}(\mathrm{Ca})$ respectively. The results for mineral contents were expressed as $\mathrm{mg} / \mathrm{kg}$ of dried sample. There after the Risk Assessment Code (RAC) of non-essential heavy metals $(\mathrm{Pb}, \mathrm{Cd}, \mathrm{Ni}, \mathrm{As}, \mathrm{Cr})$ in $\mathrm{CF}$ stem was performed as per the method described earlier ${ }^{17}$ and the calculation is as:

$\operatorname{RAC}(\%)=\left(\sum_{n=1}^{n=3} F_{n} / \sum_{n=1}^{n=6} F_{n}\right)$

Where, "Fn" is the concentration of metal in ' $n$ "th' fraction.

\section{Extraction of CF stem}

Two different methods were carried out using soxhlet as well as microwave assisted extraction methods.

\section{Extraction by soxhlet method}

$15 \mathrm{~g}$ of stem powder separately was extracted with above two methods. It was performed using Soxhlet apparatus for $3 \mathrm{hr}$ using methanol and aqueous solvents. Total volume of the system was kept $100 \mathrm{ml}$. Finally, the yield of extract was calculated after concentrated the crude extract rotary flash evaporator (water bath temperature $45^{\circ} \mathrm{C}$ ). Extracts were kept in refrigeration condition at $4^{\circ} \mathrm{C}$ for further investigation.

\section{Extraction by microwave method}

$15 \mathrm{~g}$ of dried stem powder was suspended in $150 \mathrm{~mL}$ of aqueous and methanol solution separately $(40: 60)(\mathrm{v} / \mathrm{v})$ in a $250 \mathrm{~mL}$ Teflon extraction vessel. The vessel were placed in the microwave apparatus and heated at $80 \mathrm{~s}$ at $600 \mathrm{~W}$. The vessel was allowed to cool at $25^{\circ} \mathrm{C}$ then filtered with Whatmann filter paper and dried by evaporation of obtained extract and yield was calculated. Thereafter extracts were preserved in small glass bottles under refrigeration $\left(4^{\circ} \mathrm{C}\right)$ for further experimentation.

\section{Phytochemical screening and TLC identification}

Qualitative phytochemical screening of stem extract was performed and was assessed for the existence of the phytochemicals by using the standard methods ${ }^{18-20}$ thereafter based on group of constituent present, TLC was performed and confirmed the main separated constituent in stem extract of CF.

\section{TLC study}

Various solvent systems were used for identification of main phytoconstituents (Berberine) present in the $\mathrm{CF}$ 
stem extract and the study was reported in the result section.

\section{Estimation of total alkaloids}

Total alkaloid content was determined by compared with standard Berberine Hydrochloride (BH). $1 \mathrm{mg}$ of stem extract was dissolved in methanol and $1 \mathrm{ml}$ of $2 \mathrm{~N} \mathrm{HCl}$ was added and filtered. The solution was transferred to a separating funnel. Then $5 \mathrm{ml}$ of bromocresol green solution and $5 \mathrm{ml}$ of phosphate buffer were added and were shaken with 1, 2, 3 and $4 \mathrm{ml}$ chloroform by vigorously. Then collected in a $10-\mathrm{ml}$ volumetric flask and diluted to the volume with chloroform. Series of standard solutions at concentration of 20,40, 60, 80 and $100 \mu \mathrm{g} / \mathrm{ml}$ were prepared. Finally, the absorbance for test and standard solutions were determined against the reagent blank at $418 \mathrm{~nm}$ with an UV/Visible spectrophotometer. The total alkaloid content was expressed as $\mathrm{mg}$ of $\mathrm{BH} / \mathrm{g}$ of extract. ${ }^{21}$

\section{Estimation of total phenolic content}

Folin-Ciocalteu method ${ }^{22}$ is used to determine total phenolic content of the sample. $0.2 \mathrm{~mL}$ of Folin-Ciocalteu reagent $(10 \% \mathrm{v} / \mathrm{v})$ is added to $0.1 \mathrm{~mL}$ of the sample and is vortexed for $5 \mathrm{~min}$, followed by addition of $0.8 \mathrm{~mL}$ of sodium carbonate. This reaction mixture was incubated for $2 \mathrm{hr}$ at room temperature. The absorbance was measured at $765 \mathrm{~nm}$. The same procedure was followed for the standard solution of gallic acid. The total phenolic content in the extract were expressed as $\mathrm{mg}$ of Gallic Acid Equivalent (GAEs) per g of extract (GA mg/g).

\section{Estimation of total flavonoid content}

Aluminum chloride colorimetric method was used for flavonoids determination. ${ }^{23} 0.5 \mathrm{~mL}$ of each plant extract was separately mixed with $1.5 \mathrm{~mL}$ of methanol, $0.1 \mathrm{~mL}$ of $10 \%$ aluminum chloride, $0.1 \mathrm{~mL}$ of $1 \mathrm{M}$ potassium acetate and $2.8 \mathrm{~mL}$ of distilled water. The reaction mixture was allowed to stand at room temperature for 30 min and the absorbance of the reaction mixture was measured at $415 \mathrm{~nm}$. Quercetin was used as standard and the flavonoid content is expressed in terms of $\mathrm{mg}$ of Quercitin Equivalents (QE) per g of extract.

\section{Statistical analysis}

Data are expressed as mean \pm SD from three replications. For correlation study among the yield, elements contents and total phytochemical presents, one-way ANOVA test followed by post Tukey's test $(p<0.05)$ was performed. Thereafter, elemental contents in powdered drug along with various solvent extracted samples were statistically analysed through one way ANOVA test followed by Dunnett comparative test. $p$ values less than 0.05 were considered to be statistically significant.

\section{RESULTS}

\section{Proximate analysis}

\section{Ash content}

Total ash, alcohol soluble and acid insoluble ash was determined and results were tabulated in Table 1.

\section{Moisture content}

Air dried powdered stem sample of CF was determined for moisture content and result revealed the percentage total moisture content was $3.67 \pm 0.11$.

Extractive values

Ethanol and water-soluble extractive values were determined as per procedure described in the method and results were depicted in Table 2.

\section{Crude fibres}

Percentage content of crude fibres of CF stem was determined and resulted percentage presence of fibres in CF crude powder is $34.13 \pm 0.04$. Thereafter arrangement of fibres was confirmed with the SEM study (Figure 1) where fibres were arranged tightly by overlapped each other.

\section{Powder microscopy}

Detail powder microscopy of the stem powder of CF was carried out and resulted presence of cork, cortex, Tracheid, fibres, Prismatic calcium oxalate crystals, stone cells, Medullary rays, pitted and spring shaped phloem fibres etc (Figure 2). Further SEM study confirmed the presence of observed cell components in CF stem powder (Figure 3).

\section{Elemental analysis for powdered sample}

Various elements such as $\mathrm{Zn}, \mathrm{Fe}, \mathrm{Cu}, \mathrm{Na}, \mathrm{K}, \mathrm{Ca}, \mathrm{Pb}$, $\mathrm{Cd}, \mathrm{Cr}, \mathrm{Ni}$ and As were determined and resulted much

\begin{tabular}{|c|c|}
\hline \multicolumn{2}{|c|}{ Table 1: Determination of ash content. } \\
\hline Type of ash content & Ash values (\%) \\
\hline Total ash & $2.86 \pm 0.11$ \\
\hline Ethanol soluble ash & $1.62 \pm 0.03$ \\
\hline Acid insoluble ash & $0.94 \pm 0.01$ \\
\hline
\end{tabular}

Mean $\pm \mathrm{SD}_{i}(n=3)$

\begin{tabular}{|c|c|}
\hline \multicolumn{2}{|c|}{ Table 2: Determination of extractive value. } \\
\hline Type of extractive value & Extractive values (\%) \\
\hline Alcohol soluble & $5.82 \pm 0.01$ \\
\hline Water soluble & $11.30 \pm 0.03$ \\
\hline
\end{tabular}

Mean \pm SD; $(n=3)$ 
higher content of $\mathrm{Cu}, \mathrm{Fe}$ and $\mathrm{Zn}$ in stem powder of CF (Table 3). Thereafter same elements were analyzed for two different methods of extracted (Soxhlet and Microwave) sample (Table 4). Results revealed significant increased in content of elements by microwave aqueous extracted sample than other methods but nonsignificant decreased in methanolic extracted samples.

\begin{tabular}{|c|c|c|}
\hline \multicolumn{2}{|c|}{ Table 3: Content of various elements in CF stem } \\
powder.
\end{tabular}

Mean \pm SD, $n=3 ;$ *RAC: $<1$ (category 1, no risk); 1-10 (category 2, low risk); >1030; (category 3, medium risk); >30-50 (category 4 , high risk) and >50 (category 5 , very high risk)

\section{Extraction}

There were two different methods applied for extractions viz. soxhlet and microwave and resulted higher percentage of yield with microwave extracted methanol CF stem extract (46.66\%) (Table 5).

\section{Phytochemical Screening}

Various chemical tests were performed as per the above described method for both the extracted sample and revealed the presence of carbohydrate, glycoside, phenols, alkaloid, saponin, flavonoids and traces of volatile oil. Detailed study was showed in Table 6.

\section{TLC study}

Various solvents were applied and standardized the method with n-butanol, acetic acid and water (8:1:1) for the presence of main active constituent (Berberine). The $R_{f}$ was found 0.62 (Figure 4).

\section{Total Alkaloid content}

Both the extracted samples were evaluated for total alkaloid content by compared with standard berberine hydrochloride and resulted methanol stem extract of CF gave more content of alkaloid than aqueous extract. Furthermore, the result was significantly higher in microwave extracted methanolic sample $(23.40 \mathrm{mg} / \mathrm{g})$ than Soxhlet extracted CF stem extracts (Table 7, Figure $5)$.

\begin{tabular}{|c|c|c|c|c|c|}
\hline \multirow[t]{2}{*}{ Elements } & $\begin{array}{c}\text { Soxhleted aqueous } \\
\text { extract }\end{array}$ & $\begin{array}{c}\text { Soxhleted methanol } \\
\text { extract }\end{array}$ & $\begin{array}{c}\text { Microwaved } \\
\text { aqueous extract }\end{array}$ & $\begin{array}{c}\text { Microwaved } \\
\text { methanol extract }\end{array}$ & $\begin{array}{c}\text { Response of } \\
\text { extracts to RAC }\end{array}$ \\
\hline & Content (mg/kg) & Content (mg/kg) & Content (mg/kg) & Content (mg/kg) & \\
\hline $\mathrm{Fe}$ & $7.41 \pm 0.02^{\mathrm{a}, \mathrm{b}}$ & $6.24 \pm 0.11^{a, b}$ & $14.24 \pm 0.03^{b}$ & $6.23 \pm 0.04^{a, b}$ & -- \\
\hline $\mathrm{Cu}$ & $1.07 \pm 0.02^{\mathrm{a}, \mathrm{b}}$ & $0.57 \pm 0.04^{\mathrm{a}, \mathrm{b}}$ & $2.04 \pm 0.10^{b}$ & $0.56 \pm 0.11^{\mathrm{a}, \mathrm{b}}$ & -- \\
\hline $\mathrm{Zn}$ & $2.03 \pm 0.11^{a, b}$ & $0.87 \pm 0.22^{a, b}$ & $3.11 \pm 0.20^{b}$ & $0.86 \pm 0.02^{a, b}$ & -- \\
\hline $\mathrm{Pb}$ & $0.45 \pm 0.01^{b}$ & $0.18 \pm 0.02^{a, b}$ & $0.57 \pm 0.01^{b}$ & $0.19 \pm 0.01^{\mathrm{a}}$ & (1) \\
\hline $\mathrm{Cd}$ & $0.62 \pm 0.11^{b, c}$ & $0.40 \pm 0.03^{a, b}$ & $0.67 \pm 0.10^{b, c}$ & $0.40 \pm 0.10^{a, b}$ & (1) \\
\hline $\mathrm{Cr}$ & $0.16 \pm 0.02^{b, d}$ & $0.07 \pm 0.20^{\mathrm{a}, \mathrm{b}}$ & $0.24 \pm 0.03^{b, d}$ & $0.08 \pm 0.02^{\mathrm{a}, \mathrm{b}, \mathrm{d}}$ & (1) \\
\hline $\mathrm{Ni}$ & $0.18 \pm 0.12^{a, b}$ & $0.16 \pm 0.01^{a, b}$ & $0.28 \pm 0.30^{b}$ & $0.16 \pm 0.11^{a, b}$ & (1) \\
\hline As & $0.34 \pm 0.03^{a}$ & $0.30 \pm 0.04^{\mathrm{a}, \mathrm{d}}$ & $0.40 \pm 0.11^{c, d}$ & $0.30 \pm 0.01^{a, d}$ & (1) \\
\hline $\mathrm{Na}$ & $11.14 \pm 0.11^{a, b}$ & $3.31 \pm 0.11^{\mathrm{a}, \mathrm{b}}$ & $14.22 \pm 0.32^{b}$ & $3.32 \pm 0.03^{a, b}$ & -- \\
\hline K & $18.32 \pm 0.01^{a, b}$ & $14.22 \pm 0.02^{a, b}$ & $22.11 \pm 0.04^{b}$ & $14.24 \pm 0.04^{\mathrm{a}, \mathrm{b}}$ & -- \\
\hline $\mathrm{Ca}$ & $14.10 \pm 0.02^{a, b}$ & $4.28 \pm 0.03^{\mathrm{a}, \mathrm{b}}$ & $18.23 \pm 0.11^{\mathrm{b}}$ & $4.30 \pm 0.01^{\mathrm{a}, \mathrm{b}}$ & -- \\
\hline $\begin{array}{l}\text { Mean } \pm S D, n=3 ; \\
\text { high risk) } \\
\text { Same letter(s) in } \\
\left({ }^{* *} p<0.01\right)\end{array}$ & $\begin{array}{l}\text { category } 1, \text { no risk); } 1 \\
\text { r row represent non- }\end{array}$ & $\begin{array}{l}\text { tegory } 2 \text {, low risk) }>10 \\
\text { cant difference betwee }\end{array}$ & $\begin{array}{l}\text { egory } 3 \text {, medium } r \\
\text { mples } b=\text { high sig }\end{array}$ & $\begin{array}{l}\text { o-50 (category } 4 \text {, hig } \\
\left.t{ }^{(* * *} p<0.001\right) ; c=\text { sign }\end{array}$ & $\begin{array}{l}\text { and }>50 \text { (category } 5 \text {, ve } \\
\left({ }^{*} p<0.05\right) ; d=\text { significa }\end{array}$ \\
\hline
\end{tabular}


Table 5: Percentage yield of CF stem extract.

\begin{tabular}{|c|c|c|}
\hline Methods & Solvents & Yield (\%) \\
\hline \multirow{3}{*}{ Soxhlet } & Aqueous & 21.70 \\
\cline { 2 - 3 } & Methanol & 28.21 \\
\hline \multirow{2}{*}{ Microwave } & Aqueous & 32.18 \\
\cline { 2 - 3 } & Methanol & 46.66 \\
\hline
\end{tabular}

Total Phenolic content

Content of total phenolics was estimated for both the extracted methods in two different solvent extracted CF sample. Result revealed microwave extracted methanolic CF stem sample gave higher content of phenolics (22.47 $\mathrm{mg} / \mathrm{g}$ ) than other extracted method (Table 7, Figure 5).

\section{Total Flavonoid content}

The same trend followed for this parameter too. The content of flavonoid also showed higher in microwave extracted methanolic sample $(19.10 \mathrm{mg} / \mathrm{g})$. It is also observed that soxhlated methanol stem CF sample also gave higher content $(15.20 \mathrm{mg} / \mathrm{g})$ of flavonoids than aqueous sample (Table 7, Figure 5).

Elements present in powdered drug were compared with elements present in various modes of extracted samples such as Soxhlet and microwave methods using aqueous and methanol solvents and the result tabulated in Table 8.

\section{DISCUSSION}

The proximate analysis in terms of quantitative analysis of various parameters such as total ash, alcohol soluble and acid insoluble ash, moisture content, extractive val- ues and crude fibers were determined which are useful for setting standard for the said plant. These analyses also help to detect adulteration or any unintentional mixture in original drug as well as purity of the sample. Generally morphological identification of powder sample is very difficult until some analysis done for the powder. Based on that, the present investigation was carried out with proximate analysis of the powdered CF stem sample. In case of total ash content, acid insoluble and alcohol soluble ash contents the result showed within the limit which was reported by earlier literature. ${ }^{2}$ The moisture content is determined to know about the stability of the phytoconstituents in the plants because more moisture content leads chemical decomposition by the microbial contamination. Hence less moisture content prevents microbial growth and increase the stability of plant constituents. ${ }^{24,25}$ Therefore in the present study, moisture content for dried CF stem was determined and resulted very less moisture content which indicated stability of the phytochemicals present in the $\mathrm{CF}$ stem and the result followed similar to the earlier cited article. $^{2}$

Generally extractive value provides an idea about the nature of the phytochemicals present and their solubility in which the respective constituents are extracted from the herbal plants. Furthermore, extractive value also applied for such materials whose suitable chemical or biological assay does not exists. Hence in the next step, extractive value was determined using two different solvents such as water and alcohol for the CF stem powder. The result reported higher percentage of water-soluble extractive than alcohol soluble extractive. This indicated that maximum phytoconstituents of $\mathrm{CF}$

\begin{tabular}{|c|c|c|c|c|}
\hline \multirow[t]{2}{*}{ Phytoconstituents } & \multicolumn{2}{|c|}{ Soxhlet extract } & \multicolumn{2}{|c|}{ Microwave extract } \\
\hline & Aqueous & Methanol & Aqueous & Methanol \\
\hline Protein & - & + & - & ++ \\
\hline Lipid & - & - & - & - \\
\hline Carbohydrate & + & - & - & + \\
\hline Alkaloids & + & + & + & ++ \\
\hline Glycoside & + & + & ++ & ++ \\
\hline Phenolics & + & + & ++ & ++ \\
\hline Saponins & + & + & ++ & ++ \\
\hline Flavonoids & + & ++ & ++ & ++ \\
\hline Terpenoids & - & - & - & + \\
\hline Steroids & - & - & - & - \\
\hline Tannins & - & - & -- & - \\
\hline Resins & - & - & + & - \\
\hline
\end{tabular}

$(+)=$ Weak positive $(++)=$ Strong positive; $(--)=$ Absent 


\begin{tabular}{|c|c|c|c|c|}
\hline \multicolumn{2}{|c|}{ Table 7: Total alkaloids, Phenolics and Flavonoids contents in CF stem extract. } \\
\hline \multirow{2}{*}{ Methods } & Solvents & $\begin{array}{c}\text { Total alkaloid content } \\
(\mathbf{m g} / \mathbf{g})\end{array}$ & $\begin{array}{c}\text { Total Phenolic } \\
\text { content }(\mathbf{m g} / \mathbf{g})\end{array}$ & $\begin{array}{c}\text { Total Flavonoid content } \\
\mathbf{( m g / g )}\end{array}$ \\
\hline \multirow{2}{*}{ Soxhlet } & Aqueous & $17.22 \pm 0.0^{2^{* * *}}$ & $17.11 \pm 0.0^{1+* *}$ & $14.54 \pm 0.0^{3^{* * *}}$ \\
\cline { 2 - 5 } & Methanol & $19.11 \pm 0.0^{1+* *}$ & $19.21 \pm 0.0^{4^{* * *}}$ & $15.20 \pm 0.0^{1+* *}$ \\
\hline \multirow{2}{*}{ Microwave } & Aqueous & $20.67 \pm 0.1^{1+* *}$ & $20.32 \pm 0.1^{2^{* * *}}$ & $16.81 \pm 0.1^{0^{* * *}}$ \\
\cline { 2 - 5 } & Methanol & $23.40 \pm 0.0^{3^{* * *}}$ & $22.47 \pm 0.0^{2^{* * *}}$ & $19.10 \pm 0.0^{3^{* * *}}$ \\
\hline F- value & & 5822 & 6204 & 2971 \\
\hline $\mathrm{R}^{2}$ & & 1.000 & 1.000 & 0.999 \\
\hline
\end{tabular}

Mean $\pm \mathrm{SD}_{i} n=3$ (replicated 3 times); One-way ANOVA study where $p<0.0001=$ highly significant; $p<0.05=$ significant when Tukey's all pairs comparison test was carried out.

Table 8: comparative study of elements in various modes of extracts in various solvents.

\begin{tabular}{|l|l|l|l|l|l|}
\hline Elements & \multicolumn{1}{|c|}{$\begin{array}{c}\text { Powdered CF } \\
\text { stem } \\
\text { sample }\end{array}$} & $\begin{array}{c}\text { Soxhleted aqueous } \\
\text { extract }\end{array}$ & $\begin{array}{c}\text { Soxhleted methanol } \\
\text { extract }\end{array}$ & $\begin{array}{c}\text { Microwaved aqueous } \\
\text { extract }\end{array}$ & $\begin{array}{c}\text { Microwaved methanol } \\
\text { extract }\end{array}$ \\
\hline & & Content $(\mathrm{mg} / \mathrm{kg})$ & Content $(\mathrm{mg} / \mathrm{kg})$ & Content $(\mathrm{mg} / \mathrm{kg})$ & $\mathrm{Content}(\mathrm{mg} / \mathrm{kg})$ \\
\hline $\mathrm{Fe}$ & $6.24 \pm 0.02$ & $7.14 \pm 0.02^{* * *}$ & $6.24 \pm 0.01$ & $14.24 \pm 0.03^{* * *}$ & $6.23 \pm 0.01$ \\
\hline $\mathrm{Cu}$ & $0.57 \pm 0.11$ & $1.07 \pm 0.02^{* * *}$ & $0.57 \pm 0.04$ & $2.04 \pm 0.10^{* * *}$ & $0.56 \pm 0.11$ \\
\hline $\mathrm{Zn}$ & $0.83 \pm 0.02$ & $2.03 \pm 0.01^{* * *}$ & $0.84 \pm 0.02$ & $3.11 \pm 0.20^{* * *}$ & $0.84 \pm 0.02$ \\
\hline $\mathrm{Pb}$ & $0.17 \pm 0.02$ & $0.47 \pm 0.02^{* * *}$ & $0.17 \pm 0.03$ & $0.51 \pm 0.04^{* * *}$ & $0.17 \pm 0.11$ \\
\hline $\mathrm{Cd}$ & $0.38 \pm 0.01$ & $0.62 \pm 0.01^{* * *}$ & $0.38 \pm 0.03$ & $0.67 \pm 0.10^{* * *}$ & $0.39 \pm 0.10$ \\
\hline $\mathrm{Cr}$ & $0.07 \pm 0.02$ & $0.16 \pm 0.22^{* * *}$ & $0.08 \pm 0.20$ & $0.25 \pm 0.03^{* * *}$ & $0.08 \pm 0.32$ \\
\hline $\mathrm{Ni}$ & $0.14 \pm 0.01$ & $0.19 \pm 0.12^{*}$ & $0.15 \pm 0.01$ & $0.27 \pm 0.02^{* * *}$ & $0.15 \pm 0.11$ \\
\hline $\mathrm{As}$ & $0.29 \pm 0.01$ & $0.31 \pm 0.23^{* *}$ & $0.30 \pm 0.04$ & $0.41 \pm 0.01^{* * *}$ & $0.30 \pm 0.01$ \\
\hline $\mathrm{Na}$ & $3.28 \pm 0.03$ & $11.14 \pm 0.11^{* * *}$ & $3.26 \pm 0.11$ & $14.22 \pm 0.02^{* * *}$ & $3.27 \pm 0.03$ \\
\hline $\mathrm{K}$ & $14.20 \pm 0.04$ & $18.32 \pm 0.21^{* * *}$ & $14.20 \pm 0.32$ & $22.11 \pm 0.04^{* * *}$ & $14.21 \pm 0.04$ \\
\hline $\mathrm{Ca}$ & $4.27 \pm 0.21$ & $14.10 \pm 0.22^{* * *}$ & $4.28 \pm 0.03$ & $18.23 \pm 0.11^{* * *}$ & $4.28 \pm 0.21$ \\
\hline
\end{tabular}

Mean $\pm S D, n=3$; One-way ANOVA followed by Dunnett's comparative test was performed (Powdered sample Vs different extracted samples); All elements were analyzed separately and compiled results were tabulated in single table. $p$ values: $*<0.05, * *<0.01, * * *<0.001$ were considered significant.

stem were more soluble in polar solvents. The results were correlated with the earlier literatures., ${ }^{2,11,26}$

Plant's stem are generally woody in nature and hence crude fibers are determined for the CF stem powder and resulted maximum content of small fibers. No previous literatures are quantified crude fibers in this plant and hence evidences are lacking but generally it is proved that fibers content if more in stem indicated the strength of the stem and maximum fibers are generated during the summertime (April-May months). Our CF is woody climber tree and the plant part was collected in AprilMay where content of fibers was more and it is revealed the same as reported by earlier researcher. ${ }^{27}$ Furthermore arrangement of fibers was determined by used SEM study which was the first report for this CF stem powder. Results indicated that fibers are short, strongly bound each other and compact. Mainly Sclerenchyma fibres that are present in plant fibres form secondary cell wall which are dead cells with lignin and this strengthen the plant fibres to become climber woody tree. The xylem and phloem are also responsible for thick cell wall of plant fibers and hardness due to the lignin on the outer part of their vessels. ${ }^{2}$

Thereafter many herbal industries are used raw materials in powdered form which sometimes affects the purity of drugs and much risk for adulteration or substitution. Many herbals are available whose anatomical nature is unknown. Hence powder microscopy helps in botanical identity as well as helps in monograph analysis of the crude drugs. ${ }^{28}$ with the same concept, in the present study powder microscopy of CF stem powder was carried out and finally SEM analysis was performed for confirmation of identified cells and tissue components. There is no reports on SEM study of CF stem powdered drug hence no proper evidence and this is the first report on the same.

Many literatures revealed that percentage yield varied with the solvent and methods used ${ }^{29-31}$ and the same concept was applied in the present study. Two different methods viz. soxhlet and microwave techniques 


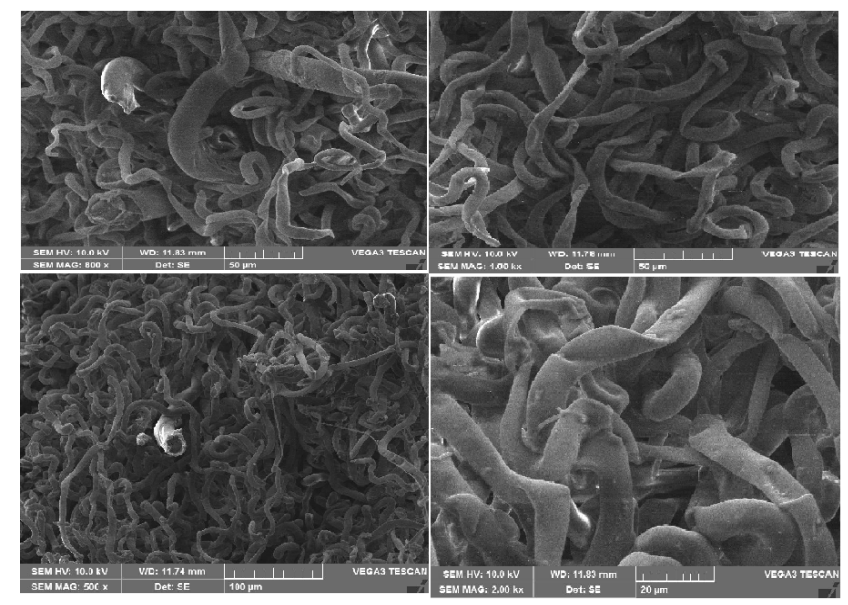

Figure 1: SEM study for arrangement of fibers of CF stem.

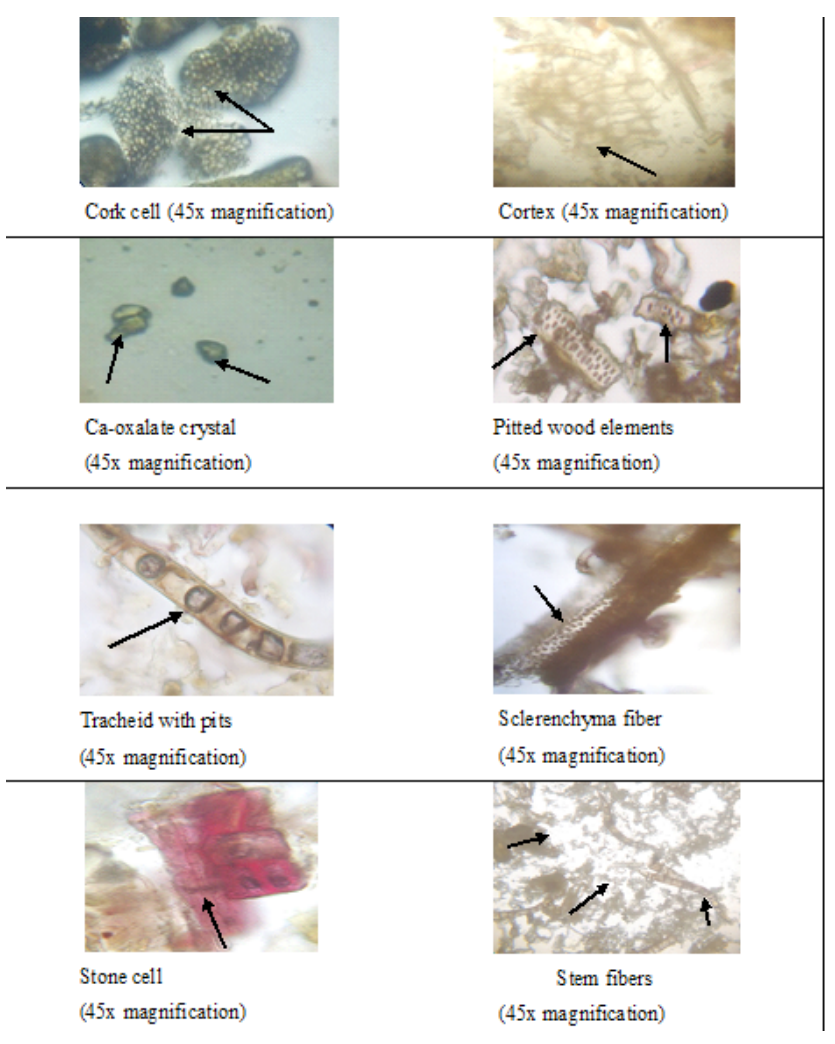

Figure 2: Powder microscopy of CF stem.

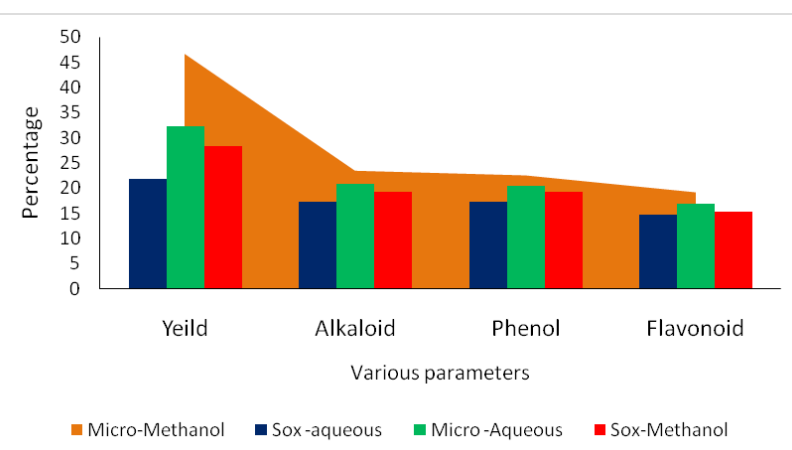

Figure 5: Effect of solvent and extraction methods on various parameters.
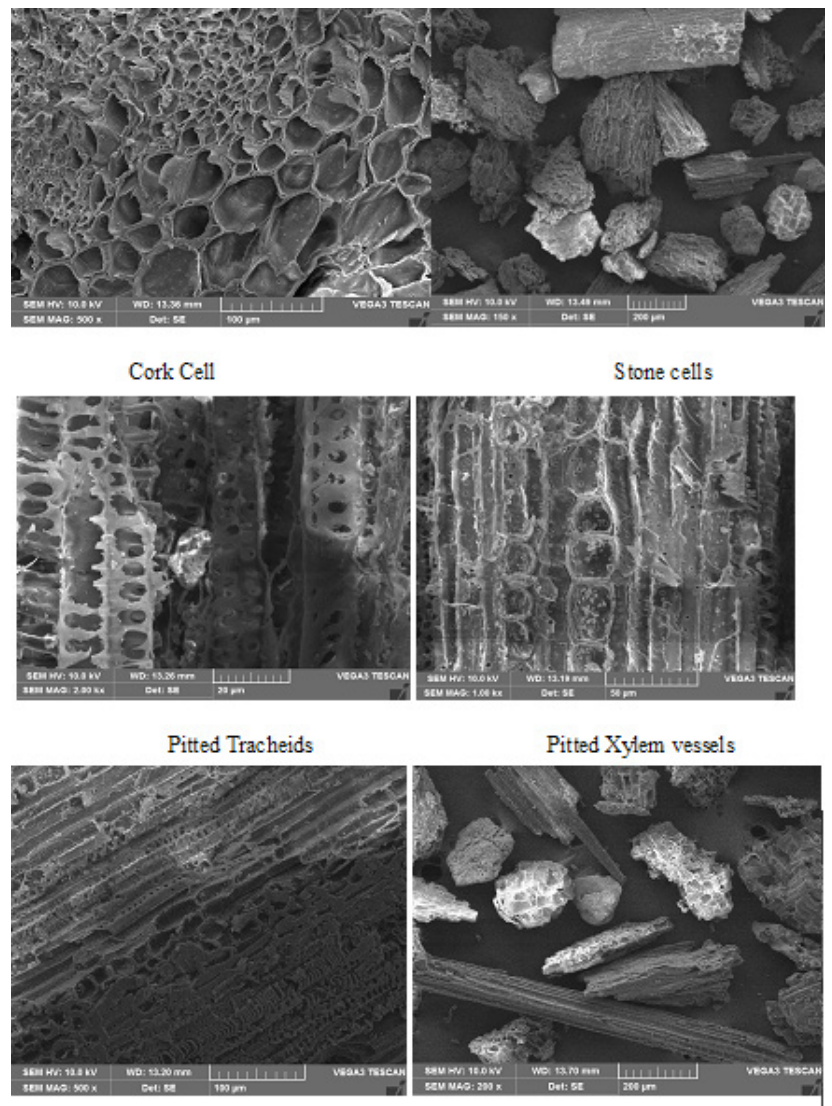

Figure 3: SEM study of powder microscopy of CF stem. n-butanol, acetic acid and water $(8: 1: 1)$

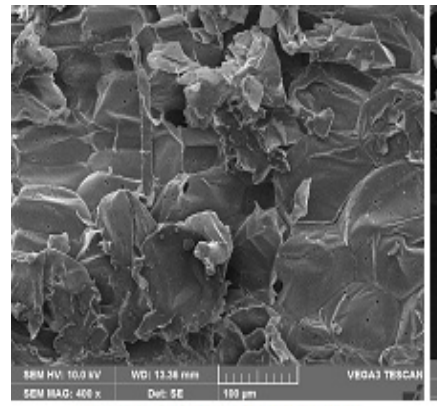

Cortex with Ca-oxalate crystal

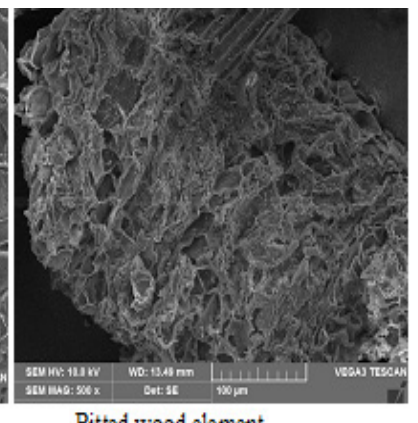

Pitted wood element
Figure 4: TLC of Berberine present in CF stem extracts.

were used for extraction of $\mathrm{CF}$ stem using aqueous and methanol solvents. Results revealed microwave assisted methanol extract gave highest yield than others because in microwave, localized temperature and pressure that causes selective migration of targeted compounds from the inside cell to the outside solvent. Not only that the radiation of microwave interacts with solvents and sample and heat is transferred by conduction, resulted disruption of hydrogen bonding that enhanced the migration of dissolved ions and helps solvent penetration into the cell sample and hence microwave extracted methanol extract gave highest yield ${ }^{30,32}$ in the present 
investigation. Several solvents may also helps to get best yields of particular compounds and hence two different solvents were used in this study due to the degrading enzymes that may be denatured or active in either of two extract ants. Furthermore, elemental analysis is one of the important parameter because various macro and microelements as well as non essential heavy elements are required to determine to understand their role in human body. Based on that, some instrumental analyses were carried out for CF stem powdered drug and the same was carried out for the extracted samples. Result revealed microwave assisted aqueous extract gave higher element contents than powdered sample. There were significant differences observed in soxhlet extracted aqueous sample, with microwave extracted aqueous sample but no significant differences observed in methanol extracted samples. This may be due to elements are more soluble in microwave aqueous extract than soxhlated aqueous extract and very less soluble in methanolic extracts. Thereafter non essential heavy metals such as $\mathrm{Pb}, \mathrm{Ni}, \mathrm{Cr}, \mathrm{Cd}$ and As were resulted very negligible amount which were below risk level but content of $\mathrm{Fe}, \mathrm{Zn}, \mathrm{Cu}, \mathrm{Na}, \mathrm{Ca}$ and $\mathrm{K}$ contents were significant higher in microwave extracted aqueous sample that had impact on the increased yield. The result was similar to the earlier literatures. ${ }^{33,34}$

The qualitative determination of plant constituents through various chemical tests is necessary to identify the presence of various groups of plant secondary metabolites and also ascertain the therapeutic efficacy. In the present study two different solvents extracts were tested chemically and revealed the presence of many important active compounds in microwave assisted aqueous extract as well as some are in microwave extracted methanol extract and this variation of results may be due to the solubility of active components in the specific solvents. ${ }^{35}$ Hence presence of phenolics, saponins, flavonoids were more prominent in microwave extracted aqueous sample whereas protein and alkaloid contents were more available in methanol extract (micro waved extraction).

Generally in late summers the content of phenolics, flavonoids and alkaloids are more in stem sample. ${ }^{36}$ Based on that the present study was carried out to estimate total phenolics, flavonoids and alkaloids in CF stem extracts and resulted higher amount of components present in microwave assisted aqueous and methanol samples. Based on the constituents present further TLC was carried out using n-butanol, acetic acid and water (8:1:1) after standardized the solvent system and clear separation of berberine alkaloid observed when compared with standard berberine hydrochloride.

\section{CONCLUSION}

The Pharmacognostic constants for the CF stem, powder microscopy and the numerical standards resulted in the present investigation is useful for the compilation of a suitable monograph for proper identification of CF plant. In this present study, two different methods and two different solvents were used for extraction and maximum yield was reported with microwave assisted methanol extract whereas element contents were more in aqueous extract with microwave extraction method. Finally concluded that percentage yield was dependent on method of extraction and solvents used.

\section{ACKNOWLEDGEMENT}

Author is thankful to Rajiv Gandhi University of Health Sciences, Bangalore, India for financial assistance of Rs. 1.5 Lakhs as research grant (Principal Investigator) for carry out the present investigation (Order No. RGU: Adv. Res.: Proposal-P-171: 2015-16 DATE: 06-01-2016).

\section{CONFLICT OF INTEREST}

The authors declare no conflict of interest.

\section{ABBREVIATIONS}

CF: Coscinium fenestratum; SEM: Scanning Electron Microscopy; BH: Berberine hydrochloride; $\mathbf{Z n : ~ Z i n c ; ~}$ Fe: Iron; Cu: Copper; Pb: Lead; Cd: Cadmium; Cr: Chromium; Ni: Nickel; As: Arsenic; Na: Sodium; K: Potassium; Ca: Calcium; RAC: Risk Assessment Code.

\section{REFERENCES}

1. Ravikumar K, Ved DK. 100 Red Listed Medicinal Plants of Conservation Concern in South India. FRLHT, Bangalore. 2000;99-103.

2. Tushar KV, George S, Remashree AB, Balachandran I. Coscinium fenestratum (Gaertn.) Colebr.-A Review on this Rare, Critically Endangered and Highly-Traded Medicinal Species. J Plant Sci. 2008;3(2):133-45.

3. Nambiar VPK, Warrier PK, Ganapathy PM. Some Important Medicinal Plants of the Western Ghats, India: A Profile. AVS Publication, IDRC, Artstock, New Delhi, India. 2000;105-20.

4. Rungsimakan S. Pharmacognostic property of Khamin Khruea. Master's degree thesis, Chulalongkorn University, Thailand. 2001;1-187.

5. Chomnawang MT, Trinapakul C, Gritsanapan W. In vitro antigonococcal activity of Coscinium fenestratum stem extract. J Ethnopharmacol. 2009;122(3):445-9.

6. Manjunatha BK, Murthuza S, Sudharshan SJ, Divakara R. Phytochemical investigation and Hepatoprotective activity of Coscinium fenestratum Colebr., A rare endangered spp., from Western Ghats of India. PARIPEX-Ind J Res. 2013;2(2):14-6.

7. Udayan PS, George S, Tushar KV, Balachandran I. Medicinal plants used by the Kaadar tribes of Sholayar forest, Thrissur district, Kerala. Ind J Trad Know. 2005a;4(2):159-63.

8. Udayan PS, George S, Tushar KV, Balachandran I. Ethnomedicinal plants used by the Oorali tribe of Idukki district, Kerala state, India. J Econ Taxon Botany. 2005b;29(1):217-20. 
9. Rai RV, Rajesh PS, Kim HM. Medicinal use of Coscinium fenestratum (Gaertn.) Colebr: a short review. Orient Pharm Experiment Medicine. 2013;13(1):1-9.

10. Madhavan SC, Bose C, Perakathusseril TM, Banerji A. Indian medicinal plant, Coscinium fenestratum- A new bio source for the multifunctional bio active molecule- ecdysterone. Inter J Herb Med. 2014;2(5):05-9.

11. Anonymous. Quality Standards of Indian Medicinal Plants. Indian Council of Medical Research, New Delhi. 2005;2:119-28.

12. Shingate V, Pallavi VB, Harshada AG, Anand PK. A comprehensive pharmacognostic review on endangered medicinal plants in Western Costal region of India. European J Biomed Pharma Sci. 2017;4(6):277-97.

13. Rema SAB, Jayanthi A, Thushar KV, Balachandran I. Anatomy of Coscinium fenestratum (Gaertn.) colebr. A critically endangered medicinal plant from Western ghats. Phytomorphology: An Inter J Plant Morphol. 2005;55(3):24958.

14. AOAC. Official Method of Analysis. $16^{\text {th }}$ edition. Association of Official Analytical Chemists, Washington, DC. 1995

15. Ajeesh KTP, Adarsh KTP, Kumuthakallavalli R, Sanyo RVN, Juliet S, Shobha $\mathrm{RT}$, et al. Physico-chemical evaluation and biochemical quantification of crude drug powder (stem) of Chassalia curviflora (Wall. ex Kurz.) Thwaites: A folk medicinal Plant. J Pharmacog Phytochem. 2014;3(4):121-4.

16. James CJ. The Analytical Chemistry of Foods. Chapman and Hall Press, New York. 1995;86.

17. Singh KP, Mohan D, Singh VK, Malik A. Studies on distribution and fractionation of heavy metals in Gomti river sediments-atributary of the Ganges. India J Hydrol. 2005;312(1):14-27.

18. Harborne JB. Phytochemical Methods. Chapman and Hall limited, London. 1973;49- 188.

19. Trease GE, Evans WC. Pharmacognosy. $11^{\text {th }}$ edition. Brailliar Tiridel Can. Macmillan Publishers. 1989;257.

20. Sofowara AE. Medicinal Plants and Traditional Medicine in Africa. $2^{\text {nd }}$ edition. Spectrum Books, Ibadan, Nigeria. 1993;289

21. Luyang Li, Long W, Wan X, Ding Q, Zhang F, Wan D. Studies on Quantitative Determination of Total Alkaloids and Berberine in Five Origins of Crude Medicine "Sankezhen". J Chromato Sci. 2015;53(2):307-11.

22. McDonald S, Prenzler PD, Antolovich M, Robards K. Phenolic content and antioxidant activity of olive extracts. Food Chem. 2001;73(1):73-84.

23. Chang $\mathrm{C}$, Yang $\mathrm{M}$, Wen $\mathrm{H}$, Chern J. Estimation of total flavonoid content in propolis by two complementary colorimetric methods. J Food Drug Anal. 2002;10(3):178-82.

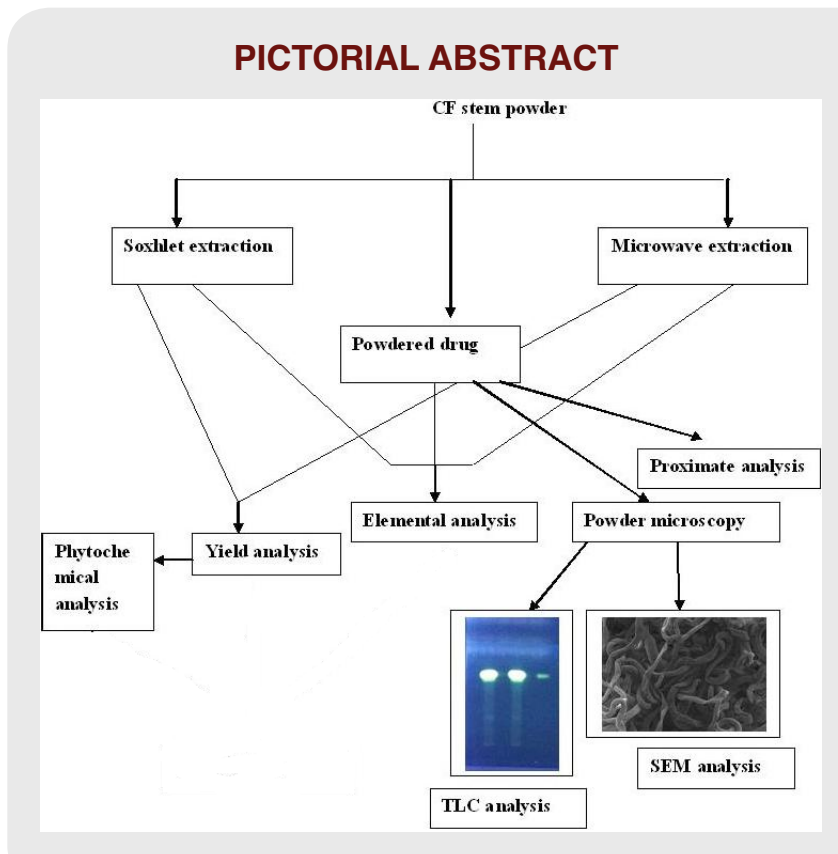

24. Hussain K, Ismail Z, Sadikun A, Ibrahim P. Proximate and qualitative analysis of different parts of Piper sarmentosum and quantification of total amides in various extracts. Phcog Res. 2009;1(3):113-9.

25. Saleem U, Hussain K, Ahmad M, Bukhari NI, Malik A, Ahmad B. Physicochemical and phytochemical analysis of Euphorbia helioscopia (L.). Pak J Pharm Sci. 2014;27(3):577-85.

26. Nagulan S, Kumar SR. Phytochemical, physicochemical and fluorescence analysis of leaf extract of Syzygium calophyllifolium walp. Asian J Pharma Clinic Res. 2016;9(1):275-8.

27. Busuttil-Griffin F, Shoemake C, Attard E, Azzopardi LM. Crude Fibre Determination of Malva sylvestris L. and Evaluation of its Faecal Bulking and Laxative Properties in Rats. Inter J Biol. 2015;7(4):1-8. doi:10.5539/ijb. v7n4p1.

28. Singh D, Aeri V, Ananthanarayana DB. Development of internet technology TIPHAM (Tool for identity of powdered herbals through analytical microscopy) for microscopic identification of crude drugs. Phcog Mag. 2018;14(55):213-6.

29. Azwanida NN. A Review on the Extraction Methods Use in Medicinal Plants, Principle, Strength and Limitation. Med Aromat Plants. 2015;4(196):21670412. doi:10.4172/2167-0412.1000196.

30. Dhanani T, Shah S, Gajbhiye NA, Kumar S. Effect of extraction methods on yield, phytochemical constituents and antioxidant activity of Withania somnifera. Arabian J of Chem. 2017;10(1):S1193-9.

31. Gahlot M, Bhatt P, Joshi J. Study on Yield of Plant Extracts Using Different Solvents and Methods. Bull Env Pharmacol Life Sci. 2018;7(6):65-7.

32. Kaufmann B, Christen P. Recent extraction techniques for natural products: Microwave assisted extraction and pressurized solvent extraction. Phytochem Anal. 2002;13(2):105-13.

33. Kumar R, Mehrotra NK, Nautiyal BD, Kumar P, Singh PK. Effect of copper on growth, yield and concentration of $\mathrm{Fe}, \mathrm{Mn}, \mathrm{Zn}$ and $\mathrm{Cu}$ in wheat plants (Triticum aestivum L.). J Environ Biol. 2009;30(4):485-8.

34. Das K, Tribedi S. Effect of $\mathrm{Zn}, \mathrm{Fe}$ and $\mathrm{Cu}$ Content on Phytochemical Investigations and Antimicrobial Potential of Alternanthera brasiliana (L.) O. Kuntze Leaf Extracts Procured From Two Different States of India. Turk J Pharm Sci. 2015;12(3):345-56.

35. Madike LN, Takaidza S, Pillay M. Preliminary Phytochemical Screening of Crude Extracts from the Leaves, Stems and Roots of Tulbaghia violacea. Inter J Pharmacog Phytochem Res. 2017;9(10):1300-8.

36. Choudhary N, Siddiqui MB, Khatoon S. Pharmacognostic evaluation of Tinospora cordifolia (Willd.) Miers and identification of biomarkers. Ind J Trad Know.

\section{SUMMARY}

CF stem powder microscopy as well as SEM study and other proximate analysis were carried out for screening of $\mathrm{CF}$ stem. Further two different methods and two different solvents were used for extraction of CF stem and maximum yield was reported with microwave assisted methanol extract whereas element contents were more in aqueous extract with microwave extraction method. The percentage yield was dependent on method of extraction and solvents used. The content of phytoconstituents positively correlated with the yield and element contents in the respective solvent used for extract preparation. 


\section{About Authors}

Dr. Kuntal Das (PhD, FICS, FAELS, FIC, FSPP), Professor, Krupanidhi College of Pharmacy, Bangalore, India, having total 16 years of Teaching \& Research Experience. He is specialized in the area of cultivation and Standardization of Medicinal plants, Tissue culture of endangered plants. Currently he is BOS (UG) member in Rajiv Gandhi University of Health Sciences, Bangalore, India. His carrier reflected with various prestigious awards and acclaims in many scientific forums, having 89 scientific research publications, 10 books and 08 book chapters.

Cite this article: Kuntal Das, Pharmacognostical and Proximal Analysis of Two different Extracts (Methanol and Aqueous) of Indian Endangered Coscinium fenestratum Stem. Indian J of Pharmaceutical Education and Research. 2019;53(4s):s710-s720. 